\title{
'THAT ANCIENT AND CHRISTIAN LIBERTY': EARLY CHURCH COUNCILS IN REFORMATION ANGLICAN THOUGHT
}

\author{
ANDRE A. GAZAL* \\ Montana Bible College
}

\begin{abstract}
This article will examine the role the first four ecumenical councils played in the controversial enterprises of John Jewel (1522-71) as well as two later early modern English theologians, Richard Hooker (1553-1600) and George Carleton (1559-1628). In three different polemical contexts, each divine portrays the councils as representing definitive catholic consensus not only for doctrine, but also ecclesiastical order and governance. For all three of these theologians, the manner in which the first four ecumenical councils were summoned and conducted, as well as their enactments touching the Church's life provided patristic norms for its rightful administration. Jewel, Hooker, and Carleton each argued that the English Protestant national Church as defined by the Elizabethan Settlement exemplified a faithful recovery of patristic conciliar ecclesiastical government as an essential component in England's overall endeavor to return to the true Church Catholic. Jewel employed these councils in order to impeach the Council of Trent's (1545-63) status as a general council, and to justify the transfer of the authority of general councils to national and regional synods under the direction of godly princes. Hooker proposes the recovery of general councils as a means of achieving Catholic consensus within a Christendom divided along national and confessional lines while at the same time employing the pronouncements of the first four general councils to uphold the authoritative patristic and catholic warrant for institutions and practices retained by the Elizabethan Church. Finally, amid the controversy surrounding the Oath of Allegiance during the reign of James VI/1 (r. 1603-25), George Carleton devoted his extensive examination of these councils to refute papal claims to coercive authority with which to depose monarchs as an extension of excommunication. In so doing, Carleton relocates this 'coactive jurisdiction' in the ecclesiastical authority divinely invested in the monarch, making the ruler the source of conciliar authority, and arguably of catholic consensus itself.
\end{abstract}

KEYWORDS: John Jewel, Richard Hooker, George Carleton, councils, royal supremacy

\section{Introduction}

In Part I of his Apology of the Church of England (1564), Bishop John Jewel (1522-1571), in defending the Elizabethan Settlement, justified England's 
refusal to participate in the Council of Trent by excoriating Pope Pius IV's conduct of it:

If so be that Pope Pius were the man (we say not, which he would so gladly be called), but if he were indeed a man that either would account us for his brethren, or at least would take us to be men, he would first diligently have examined our reasons and would have seen what might be said with us, what against us, and would not in his bull, whereby he lately pretended a council so rashly have condemned so great a part of the world, so many learned and godly men, so many commonwealths, so many kings, and so many princes, only upon his own blind prejudices and foredeterminations, and that without hearing of them speak, or without showing cause why (Jewel 2002: 17).

Although claiming the said council to be a general council of the Church whose purpose was to reform Christendom, the pope, Jewel contends, has rendered it otherwise. Whereas a general council was to be truly representative of the whole church by affording all parts of Christendom a voice in the solemn assembly, the pope has grievously compromised this essential characteristic of a council by deprecating entire sections of Christendom (i.e. those areas which are Protestant) by condemning their magistrates and clergy without giving them opportunity to be heard, thereby denying them any substantial voice in this council. Moreover, this premature censure of Protestant states, Jewel alleges, is based on malicious prejudices rather than equitable appraisal of Protestant arguments through a properly constituted council of the Church. Thus, because there are entire sections of Christendom excluded from involvement in this council, it is not, according to the bishop, a legitimate general council.

Church councils factor prominently in Jewel's defense of the English national church under Queen Elizabeth I. This is especially the case with the first four ecumenical councils [Nicaea I (325), Constantinople II (381), Ephesus (431), and Chalcedon (451)]. These particular councils formed part of the criteria (which also included the Scriptures, the writings of the church fathers, and the custom of the primitive church) which Jewel employed to determine orthodoxy. Although Jewel cites Scripture and these other sources together, he does not regard the other three as equal to Scripture, but rather as the most accurate expositions and appropriations of it. These other sources comprise the overall witness of the early church which not only in Jewel's estimation, but also that of the magisterial reformers, spanned the first six hundred years of the Christian Church. For Jewel, the first four ecumenical councils factored significantly among these criteria as definitions of the undivided Church's catholic consensus. Moreover, these councils established the pattern for communal governance throughout the Catholic world by means of national and regional synods. 
Jewel's voluminous writings reveal not only a prodigious knowledge of the works of patristic authors, but also intimate familiarity with the ancient ecclesiastical councils, both general and regional. The apologist employed his knowledge of these councils to defend the orthodoxy of transferring the authority of general councils, (which in his estimation had become irreparably compromised) to that of national and regional synods. In so doing Jewel attempted to combine catholicity and the realty of the nation-state in the hope of advancing the comprehensive ecclesiastical reform of Western Christendom.

This article will examine the role the first four ecumenical councils played in the controversial enterprises of Jewel as well as two later early modern English theologians, Richard Hooker (1553-1600) and George Carleton (1559-1628). In three different polemical contexts, each divine portrays the councils as representing definitive catholic consensus not only for doctrine, but also ecclesiastical order and governance. For all three of these theologians, the manner in which the first four ecumenical councils were summoned and conducted, as well as their enactments touching the Church's life provided patristic norms for its rightful administration. Jewel, Hooker, and Carleton each argued that the English Protestant national Church as defined by the Elizabethan Settlement exemplified a faithful recovery of patristic conciliar ecclesiastical government as an essential component in England's overall endeavor to return to the true Church Catholic. At this point we will begin with Jewel's understanding of the role of councils based on his interpretation of the first four ecumenical councils in Part VI of his Apology of the Church of England.

\section{Jewel's Appropriation of the First Four Councils and an Alternative Conciliarism}

Part VI of Jewel's Apology of the Church of England details his doctrine of royal supremacy (the idea that the monarch exercises authority over the national church) and the role of councils. Among the objections leveled by Catholic opponents against the Elizabethan Settlement (which consisted fundamentally of the Act of Supremacy of 1559, which ascribed ecclesiastical authority to the monarch, and the Act of Uniformity of 1559 which mandated the use of a revised Book of Common Prayer which was essentially evangelical) was that the ecclesiastical changes enacted were done so without the approval of a general council, and in this case, the Council of Trent (Jewel, 2002: 103). Jewel counters the charge by contending that the Roman Church not only instituted changes that were not only without the consent of a general council, but actually broke 'the commandments of God and the decrees of the apostles' as well as nullified the ordinances and doctrines of the 'primitive church'. It is at this point that Jewel discusses the nature and 
function of councils. As it was his usual rhetorical practice, Jewel speaks about this issue in the negative with his customary sarcastic wit. Specifically, the bishop describes functions for which councils are not intended. One of these is the ratification of clear Scriptural command. 'But yet should we do... fondly, when we may hear God himself plainly speak to us in the most Holy Scriptures, and may understand by them his will and meaning, if we would afterward (as though this were of none effect) bring our whole cause to be tired by a council; which were nothing else but to ask whether men would allow as God did, and whether men would confirm God's commandment by their authority' (Jewel 2002: 103-104). Submitting clear biblical mandates for ecclesiastical sanction before preaching them, Jewel contends, would make as much sense as Christ referring his doctrine to Annas and Caiaphas and Paul his to the Sanhedrin before proclaiming them.

After sarcastically illustrating what is not the intended purpose of councils, Jewel succinctly avers his belief regarding the nature and function of councils, appealing to the legislative processes in England:

Yet truly we do not despise councils, assemblies, and conferences of bishops and learned men; neither have we done that we have done altogether without bishop or without a council. The matter hath been treated in open parliament, with long consultation and before a notable synod and convocation (Jewel 2002: 104).

Jewel acknowledges the necessary role of councils in affecting necessary changes for the Church. Like the ancient councils, present ones need to consist of bishops and theologians capable of achieving consensus in defining ecclesiastical doctrine and practice. Furthermore, Jewel maintains that the ecclesiastical settlement he is defending was one ordained by a church council. What is particularly striking about the bishop's statement here is the role he assigns to Parliament in the process. Jewel acknowledges Parliament's part in enacting the Elizabethan Settlement which fundamentally defined the Church of England (Jones 1982). In so doing, Jewel not only reports the fact of Parliament's legislative activity, but significantly, identifies this, the lawmaking body of the realm, as a church council itself. Part of the justification for this designation of Parliament as a church council significant is the fact that bishops like himself sat in the House of Lords as representatives of the Church as the 'Lords Spiritual'. Aside from this detail, what makes Jewel's identification of Parliament as a church council is the active involvement of the 'Lords Temporal' and the House of Commons in the delineation of the doctrine and worship of the Church.

Jewel proceeds to contrast the Council of Trent with the ancient councils, contending that Parliament, as a church council, reflected the ancient synods more accurately. The bishop does this first by asserting that Trent rashly condemned other Christians who 'have neither been called, heard, 
nor seen' (Jewel 2002: 104). The pope's pretended council condemned entire sectors of Christendom while simultaneously excluding their voices from it. Jewel takes this opportunity to show how councils are subject to abuse when dominated by one person seeking to accumulate power for himself by calling attention to the church fathers' own candid acknowledgement of this fact, by noting Gregory of Nazianzus' cynical assessment of councils as often being more desirous of political victory than the discovery of truth (Jewel 2002: 104). This reference to a church father who presided over one of the first four ecumenical councils (Constantinople 1) serves to highlight the inherent limitations of councils generally, and the constituted purpose of these synods as vehicles for reaching communal consensus regarding orthodox truth. 'For at that time, though the matter were labored on all sides, yet the controversies were well heard and open errors were put clean away by the general voice of all parts' (Jewel 2002: 105). However, in order for the 'open errors' to be 'put clean away', and thus, for the truth to be uncovered, 'the general voice of all parts', or the entire communal voice of the congregatio fidelium must be heard. All of Christendom must participate in a truly ecumenical determination and definition of truth. This is because such councils, especially the four ancient general councils, represent the communal consensus, and hence judgment of the whole Church.

Communal consent, for Jewel, is the definitive characteristic for a true council. For a council to be truly representative of the entire Church, all members must be able to participate fully. This fact, according to Jewel, counters the present relationship between Pope and council in which many contemporary theorists assert his superiority to it:

Well, yet then they will bring all matters before the Pope, who cannot err. To this I say, first, it is a madness to thinking that to think that the Holy Ghost, taketh his flight from a general council to run to Rome, to the end, if he doubt or stick in any matter and cannot expound it of himself, he may take counsel of some other spirit, I wot not what, that is better learned than himself. For, if this be true, what needed so many bishops, with so great charges and so far journeys, have assembled their convocation at this present at Trent? It had been more wisdom and better, at least it had been a much nearer way and handsomer, to have brought all things rather before the Pope and to have come straight forth and have asked counsel at his divine breast. Secondly, it is also an unlawful dealing to toss our matter from so many bishops and abbots and to bring it at last to the trial of one only man, specially of him who himself is appeached by us of so heinous and foul enormities and has not yet put in his answer; who has also aforehand condemned us without judgment by order pronounced and or ever we were called to be judged (Jewel 2002: 106).

High papalists, who held to papal infallibility (which would not become dogma until over three centuries later), supported papal claims to be above 
councils because of the pope's unique indwelling of the Holy Spirit which enables him by virtue of his position as Vicar of Christ to ratify the decisions of councils, including the Council of Trent. The bishop of Salisbury scornfully shows the absurdity of this position regarding papal authority by calling into question the use of councils in the first place. If indeed the pope's approval is perquisite to the validity of a conciliar decree, then why not simply dispense with councils altogether in favor of direct divine guidance from his Holiness? Next, and perhaps more importantly, to subject a conciliar matter to the sole, arbitrary judgment of one person is 'unlawful'. It directly contravenes the pattern of ecclesiastical governance established by the early church councils. Jewel further accentuates this point by employing the principle of necessary rule by the whole over any one particular part as expressed by Jerome in his Epistle to Euagrius (Jewel 2002: 107). The apologist then illustrates from patristic authors the alleged disaster of relying on the singular doctrinal judgment of the bishop of Rome. Prominent among such instances, Jewel observes, was Pope Liberius' (310-66) adoption of Arian doctrine (Jewel 2002: 107).

Jewel impugns Trent's status as a legitimate general council because it excludes entire sections of Christendom from participating, thereby denying representation to the entire congregatio fidelium, and suppresses communal consent by means of total papal control of the synod. These deficiencies alone, evidence, in the bishop's estimation, that Trent falls short of the characteristics of a general council established by the first four ecumenical councils. However, the most conspicuous defect of Trent is its brazen denial to Christian rulers of their lawful role as canonically established by the four ancient general councils. 'Wherefore do they shut out Christian kings and good princes from their convocation? Why do they uncourteously leave them out, and, as though Christian men or else could not judge, will not have them made acquainted with the cause of Christian religion, nor understand the state of their own churches?' (Jewel 2002: 113) Church councils served as necessary instruments of divinely mandated and biblically prescribed royal ecclesiastical authority (Gazal 2013: 183-272):

If the said kings and princes happen to intermeddle in such matters and take upon them to do that they may do, and the same things that we know both David and Solomon and other good princes have done, that is, they, whiles the Pope and his prelates slug and sleep or else mischievously withstand them, do bridle the priests' sensuality and drive them to do their duty and keep them still to it; if they do overthrow idols; if they take away superstition and set up again the true worshiping of God; why do they by and by make an outcry upon that such princes trouble all and press by violence into another body's office, and thereby wickedly and malaperty? What Scripture hath at any time forbidden a Christian prince to be made privy to such causes? Who but themselves alone made ever any such law? (Jewel 2002: 113) 
Arguably this is where the four ancient general councils prove especially significant in functioning as part of Jewel's criteria for determining orthodoxy; for in defining on behalf of the Universal Church, true Catholic doctrine on the basis of Scripture, these same councils confirmed royal ecclesiastical oversight as divinely ordained governance predicated upon this same doctrine.

Upon establishing the biblical mandate for royal ecclesiastical authority based on the prescriptive and thus normative function of the historical books of the Old Testament (Gazal 2013: 219-42), Jewel then moves immediately to an account of Christian Roman emperors summoning the four councils so crucial for determining orthodoxy: ‘... let us... consider, since the birth of Christ, how the church hath been governed in the Gospel's time. The Christian emperors in old time appointed the councils of bishops. Constantine called the Council of Nicaea. Theodosius the First, called the council at Constantinople. Theodosius the Second, the council of Ephesus, and Marcian, the council at Chalcedon' (Jewel 2002:116). A question that emerges here is how does Jewel make this enormous leap from the historical books of the Old Testament to the Christian Roman emperors? First, Jewel, like his Continental friends and counterparts, Peter Martyr Vermigli, and Heinrich Bullinger, includes the Christian Roman emperors and all Christian kings past and present in the general era of the New Testament who together have exercised the same oversight of the Church as their Old Testament predecessors, the kings of Israel and Judah. Thus, Jewel regarded the Christian emperors and subsequent Christian rulers as heirs to the same ecclesiastical authority held and exercised by the kings of Israel and Judah. The narrative record of the Old Testament kings was the source from which the later Christian princes derived this authority granted by God. Finally, he included the Christian Roman emperors and later Christian rulers in the era of the New Testament.

While this may well account for the ecclesiastical authority exercised by the Christian Roman emperors, particularly in their summoning the first four general councils, how would this be normative for a Christendom divided into autonomous nation states and free cities? Jewel accounts for the continuing possession and exercise of this biblically prescribed ecclesiastical authority by the rulers of nation-states by employing a certain historical interpretation of imperial power employed by many contemporary and medieval theorists. When the Roman Empire in the West dissolved (with the papacy's assistance), the imperial authority passed on to the kings of the Christian nation-states, making the Holy Roman Emperor a first among equals (Jewel 2002: 117; Gazal 2013: 268-71; Bray 1994: 78-79). The transferal of imperial power to the rulers of Christian nation-states served to empower 
them to perform their sacred duty towards the Church by means of that institution canonized by the early church, the church council.

Even though the council which the pope summoned nullifies its status as a general council by its unilateral papal control and exclusion of other Christians, the rulers of Christian states can still exercise their biblically mandated task of reforming the Church by enacting reform of the churches within their realms by summoning councils within their kingdoms:

And, forsomuch as we heard God himself speaking unto us in his word, and saw also the notable examples of the old and primitive church; again, how uncertain a matter it was to wait for a general council and that the success thereof would be much more uncertain; but specially, forsomuch as we were most ascertained of God's will and counted it a wickedness to be too careful and overcumbered about the judgments of mortal men; we could no longer stand taking advice with flesh and blood but rather thought good to do the same thing that both might rightly be done and hath also many a time been done, as well of good men as of many catholic bishops; is, to remedy our own churches by a provincial synod (Jewel 2002: 123-124).

Since the Council of Trent does not qualify as a general council, and a legitimate one conducted according to ancient canons is not likely to convene soon, Christian rulers can accomplish the same objectives through an agency frequently utilized by the early church and advocated by the church fathers, the provincial, or national synod. Jewel notes that the same fathers themselves resorted to such assemblies before appealing to general councils (Jewel 2002: 124). In fact, the doctrines and practices defined by general councils were first determined by provincial synods. Moreover, such synods predate the general councils. For instance, as the bishop observes, Cyprian presided over several synods in Carthage which drafted canons for use of the church there and those in the surrounding areas (Jewel 2002: 124). Moreover, the local councils of Ancyra (314) and Gangra (340) convened to address standards of conduct and condemn the Manichaeans without any prior urging of a general council (Jewel 2002: 124). These local synods, like the third Council of Carthage obliged its attendees, who were mostly bishops, to meet as a synod at least once a year (Jewel 2002: 124). Furthermore, the general councils of Nicaea and Chalcedon decreed that the bishops meet in provincial synods regularly (Jewel 2002: 124). In relation to the first four general councils as among the criteria for determining orthodoxy, this is significant in that these councils, especially Nicaea and Chalcedon, prescribe the regular and consistent convening of regional and provincial synods.

Based upon his reading of the ancient councils, Jewel assigns extraordinary authority to provincial and national synods. Specifically, he ascribes to 
them the power to correct enactments by higher judicatories which they deem erroneous. Jewel draws this idea from his examination of the patristic tradition (which for the bishop would be in addition to the first four councils, the writings of the fathers and the customs of the primitive church). In this regard, he calls attention to Ambrose, who, when the Emperor Constantius conferred some privileges to Auxentius, an Arian bishop, summoned a local synod in Milan to rebuke openly this action by the emperor (Jewel 2002: 124). If a local synod can rebuke the actions of an emperor, then it could, under the summons and direction of a secular ruler, correct the decisions of a general council as did Charlemagne, who in 794, convened the Synod of Frankfurt which opposed the Second Council of Nicaea's position on images (Jewel 2002: 125).

What makes Jewel's historical interpretation so astounding is that it enables him to transfer the power of general councils to regional and national ones thus effectively equating them with one another. This empowerment of national and regional councils enables them to amend or reject pronouncements by general councils. Furthermore, the bishop's exaltation of national and regional synods gives them an authority that is independent of general councils, making them effectively unnecessary, which, in Jewel's estimation, is the case since in the present world situation no true general council as prescribed by the canons and practice of the first four ecumenical councils could ever take place because of papal usurpation as well as sundry logistical impracticalities. Regional and national synods can therefore replace them because they would comply with the procedures of the ancient canons. Promotion of regional and national synods in this manner frees them to effect reform of the Church within their locales without the superfluous authorization of general councils. This virtual autonomy of regional and national synods helps ensure representation of the entire Church within a given realm. Furthermore, independent national regional synods lend themselves more as effective instruments through which the Christian ruler institutes ecclesiastical reform in conjunction with the bishops, and other clergy, as well as representatives of the laity. Finally, ascription to regional and national synods of the same authority heretofore possessed by general councils justifies the role of Parliament in legislating for the national church, thereby receiving from Jewel himself the designation of a church council operating under the supervision of the monarch as the Supreme Governor of the Church.

The existence of the separate Christian states reforming the churches within their realms through national and regional synods does not for Jewel, debase catholicity. This is because, according to Jewel, the Protestant states, by and large hold to the same doctrine, notwithstanding differences regarding nuances of specific aspects. As each realm confirms the gospel 
and advances it within its borders and promotes necessary reforms with its church through its national synods according to the received criteria of Scripture, the four ecumenical councils, the writings of the church fathers, and the custom of the primitive church, then together they will emerge as a comprehensive reformed, truly catholic body of Christendom. This is because ultimately catholicity stands upon the common possession of biblical truth. Yet, in the closing years of the sixteenth century, another apologist for the Elizabethan Settlement, Richard Hooker (1553-1600) would appropriate the patristic conciliar legacy to promote a catholic concordance within a divided Christendom as well as defend the national church against domestic Protestant detractors.

\section{Richard Hooker's Use of Patristic Conciliar Tradition}

Whereas Jewel despaired of general councils as organs of effective reform due to their alleged dominance by the pope, Hooker, on the other hand, believed that they could be recovered for the sake of re-establishing and maintaining concord amid a now-divided Christendom. Hooker predicates his argument for the utility and necessity of general councils upon appropriation of the ius gentium, that aspect of natural law that applies to relationships among nations. "Now as ther is great cause of communion, and consequently of laws for the maintenance of communion, amongst nations: So amongst nations Christian the like in regarde even of Christianitie hath bene always judged needful' (Hooker 1977a: 109). The need among nationstates to maintain cooperation for the sake of preserving the world order is even more pronounced among Christian nations. Though differing in forms of secular and ecclesiastical government as well as theological confession, the individual Christian states still comprise one Christendom, meaning that there is still fundamentally one Christianity: 'they al in that respect make one Church, as having all but One Lord, one faith, and one baptisme' (Hooker 1977a: 109). Amid diverse national theologies, at the core of Christendom is still the one faith which Christian nations must still maintain. General councils, according to Hooker, still stand as the premiere and necessary means of preserving genuine Catholic unity (Hooker 1977a: 109). In addition to the ius gentium, Hooker appeals to the divine institution of general councils as the most important reason for their continuance by the Church. 'A thing whereof Gods owne blessed spirit was the author, a thing practiced by the holy Apostles themselves, a thing always afterwards kept and observed throughout the world, a thing never otherwise then most highly esteemed of, til pride of ambition and tyrannie began by factious and vile endeavors to abuse that divine invention unto the furtherance of wicked purposes' (Hooker 1977a: 109). Next, Hooker disarms the arguments leveled by Jewel that general councils no longer serve as effective means of 
catholic governance due to abuse by the papacy. 'But as the just authoritie of civil courtes and Parliaments is not therefore to bee abolished, because sometime there is cunning used to frame them according to the private intents of men over-potent in the common welth: so the grievous abuse which hath bene of councels should rather cause men to studie how so gratious a thing may againe be reduced to that first perfection, then in regard of staines and blemishes sithens growing be held for ever in extreme disgrace' (Hooker 1977a: 109). Though the many judicial and legislative bodies of Christian Europe are subject to corruption and abuse, the existence of these vices within such assemblies does not warrant their abolition, but reform. If this should be the case for secular parliaments, then certainly it should be even more so with the divinely instituted general synods of the Church.

Hooker soon moves from defending the possibility of recovering the early church's practice of convoking general councils to appealing to the first four to define an individual's standing in the Church. As part of what is largely his conception of a greater Catholic Church in which there are many communions, Hooker references the First Council of Nicaea (325) to argue that even those deemed as heretics were part of the Catholic Church. The polemical strategy in reporting this council's judgment is readily apparent as it serves to neutralize the Romanist contention that Protestant bodies, and particularly national Protestant churches were never part of the Catholic Church (Hooker 1977a: 201). Hooker then addresses the Roman Church's place within the universal Church: '...with Rome we dare not communicate concerning sundrie hir grosse and grievous abominations, yet touching those maine partes of Christian truth, wherein they constantlie still persist, we gladly acknowledge them to be of the familie of Jesus Christ, and our hartie prayer unto God almightie is, that being conjoyned so farre foorth with them, they may at the length, (if it be his will) so yield to frame and reforme them selves, that no distraction remaine in any thing, but that we all may with one hart and one mouth glorifie God the father of our Lord, and Saviour, whose Church we are' (Hooker 1977a: 202). The essentials of the Faith comprised the apostolic teaching expressed in the Creeds of the Church as drafted by the first four councils (Hooker 1977a: 206). Assent to the formulae expressed by the Creeds determined, for Hooker, membership in the one Church as they represented Apostolic teaching. Even if one part of the Church is greatly flawed in other areas as the Roman Church was for Hooker, subscription to the formularies of faith drafted by the Council of Nicaea, and the following three councils meant that it was still genuinely part of one catholic Church.

The theology of the Nicene Creed, according to Hooker, provides patristic warrant for the use of specific elements of the reformed liturgy contained in the Book of Common Prayer. Specifically, Hooker defended the citing of 
the 'Gloria Patri' at the end of the Psalms as well as at other salient points of the liturgy. The regular repetition of this formula succinctly affirms the Trinitarian orthodoxy declared in the Creed within the same liturgy which functioned as the public vehicle through which the Church corporately confessed and learned the true faith (Hooker 1977b: 174). This is the reason why Hooker additionally defends the regular citation of the NicenoConstanipolitan Creed in the communion service of the liturgy (Hooker 1977b: 211-213).

For Hooker, the first four ecumenical councils further provided authoritative catholic consensus for the manner in which the Church of England exercised spiritual jurisdiction, a central feature of which was the administration of church discipline in the form of penance. This is the prime subject of Book VI of Hooker's Lawes of Ecclesiastical Politie. Following his discussion concerning the nature of spiritual jurisdiction in chapter 1, Hooker, in chapters 2 and 3, distinguishes two types of penitence which this spiritual jurisdiction is to help induce. The first, and primary type of penitence is one's internal, 'private dutie towards God', and the second, an external expression of the first before the Church (Hooker 1981: 6). Throughout the remainder of chapter 3 , and the whole of chapter 4 , Hooker interacts extensively with the three parts of penance defined by medieval scholastic theology: contrition, confession, and satisfaction. It is in the section on satisfaction that Hooker makes considerable use of the Council of Nicaea's canon on penance (Hooker 1981: 54). It is this satisfaction, Hooker observes, that 'importeth Acceptation, Reconciliation and Amitie' (Hooker 1981: 5455). Though, Hooker avers Christ's 'one "most pretious and proptiatorie sacrifice" hath thereby once reconciled us to God', 'wee are not for that cause to thinck any office of penitence, eyther needles, or fruitles, on our owne behalf: For then would not God require any such duties att our hands' (Hooker 1981: 55). Moreover, God, because of Christ's satisfaction and high priestly intercession, accepts such acts of pious devotion (Hooker 1981: 55). Among such deeds, Hooker specifically identifies prayers, fasts, and alms as works of satisfaction (Hooker 1981: 60). Although the penitent could perform such acts privately before God, there were other instances, however, in which the early church insisted they be exhibited publicly before the Church. 'Now although it suffise, that the offices wherewith wee pacifye God, or private men bee secretly done; yet in cases, where the Church must be alsoe satisfied, it was not to this end and purpose unnecessary, that the ancient discipline did further require outward signes of contrition to be shewed, confession of sinnes to be made openly, and those works to be apparent, which served as testimonies of Conversion before men' (Hooker 1981: 63). This is where Hooker specifically appropriates the canons of the Council of Nicaea as representing the patristic consensus regard- 
ing the necessity of demonstrating the genuineness of repentance before the Church (Hooker 1981: 64). As interpreted by Hooker, the Council of Nicaea's purpose in emphasizing public penance was the restoration of the penitent to full standing in the Church by way of re-admission to the Eucharist. Moreover, the Council, according to Hooker, vested the bishop with the authority to regulate the severity of the prescribed acts of satisfaction according to the state of the individual penitent. It should be noted that Hooker's detailed discussion of this canon primarily serves the purpose of critiquing the Roman sacrament of penance, which obscured the force of canonical penance with its stress on auricular confession, as well as its use as a source of revenue. Hooker will, in the next book of the Lawes appeal to this same council as providing representative patristic authorization for the institution of episcopacy in which the exercise of spiritual jurisdiction is vested.

Book VII of the Lawes contains Hooker's defense of episcopacy against the objections of the Presbyterians. Both the composition of the Council of Nicaea and its canons serve as confirmation by the early church for this form of ecclesiastical government. This, according to Hooker, is evidenced by the fact that the council itself functioned as a vehicle of collective episcopal authority. Furthermore, this first of the ecumenical councils formally recognized gradations within the episcopal office as indicated by its ascription of greater dignity to Metropolitans than to other sees. 'The great Council of Nice, was after our Savior Christ but three hundred twenty-four years, and in that Council, certain Metropolitans are said even then to have had ancient pre-eminence and dignity above the rest namely the Primate of Alexandria, of Rome, and of Antioch' (Hooker 1981: 193). The next three councils defined varying degrees of rank among the Metropolitans themselves. "Threescore years after this there were Synods under the Emperor Theodosius, which Synod was the first at Constantinople, whereat on hundred and fifty bishops were assembled: at which council it was decreed that the Bishop of Constantinople should not onely be added unto the former Primates, but also that his place should be second amongst them, the next to the Bishop of Rome in dignity. The same decree again renewed concerning Constantinople, and the reason thereof laid open in the Council of Chalcedon' (Hooker 1981: 193). By its regulatory acts, the Council of Nicaea did not institute episcopacy, but rather affirmed that form of ecclesiastical governance which the Church heretofore had generally maintained since apostolic times throughout most parts of the world. 'Let men therefore hereby judge of what continuance this order which upholdeth degrees of Bishops must needs have been, when a general Council of three hundred years after Christ doth reverence the same for antiquities sake, as a thing which has been even then of old observed in the most renowned parts of 
the Christian World' (Hooker 1981: 195). The Council of Nicaea as well as the following three ecumenical councils expressed the Church's general consensus regarding an institution believed essential to its governance.

John Jewel and Richard Hooker appealed to the function and practice of the first four ecumenical councils as apologists for the Elizabethan Church. Jewel appropriated these councils as patristic models of consensus, which defined orthodoxy, thereby serving as an essential part of the criteria for determining correct doctrine and practice in an effort to impeach papal authority over church councils as well as much contemporary Roman doctrine and practice. Hooker, towards the end of the sixteenth century, appealed to the same councils to establish further the Elizabethan Church's continuity with the ancient Catholic Church over against the criticisms of its institutions and practices by the Puritans. Moreover, unlike Jewel, who gave up on the continuing usefulness of general councils, thereby transferring their authority to national and regional synods, Hooker sought to revive hope for the recovery of the ancient institution as a vehicle through which a diverse, but nevertheless 'catholic' Christendom could express its consensus on the basis of 'one Lord, one faith, and one baptism'.

With the passing of Elizabeth, the throne of England went to James VI of Scotland (Now James I of England as well) in 1603. By the time of his accession, royal supremacy was the law of the land. As a monarch deeply committed to the divine right of kings, James would earnestly strive to exercise the supremacy as the divinely appointed guardian of the Church. Moreover, he would eruditely defend his divinely invested ecclesiastical authority against Catholic objections in his own polemical works some of which were occasioned by the controversy over the Oath of Allegiance, which engulfed the early part of James' reign in England. To bolster the king's position regarding the Oath of Allegiance, polemicists again would utilize scholarship on the first four ecumenical councils. Representative of the appropriation of such scholarship was Jurisdiction Regall, Epsicopall, Papall (1610) by George Carleton.

\section{Patristic Conciliar Consensus on Royal Coercive Ecclesiastical Authority: George Carleton's Exposition of the Councils}

Published in 1610, at the height of the Oath of Allegiance controversy, the main argument of this work is that the pope's claim to 'coactive', or coercive power from which stems his authority to depose the civil magistrate is illegitimate. In substantiating his thesis, Carleton distinguishes the types of power lawfully possessed by kings and bishops while incisively critiquing that asserted by the pope. On biblical and historical grounds, Carleton contends that external, coercive power did not exist in the church during the period in which there were no Christian magistrates. Rather, the only pow- 
er that the church possessed was that of spiritual jurisdiction, which did not in any way lead to coercive authority. Even the church's corrective power of excommunication, Carleton maintains, was not coercive. 'Coactive' authority, by divine appointment, has, and always will be the sole property of princes.

Carleton's treatise appears to represent employment of criteria for determining orthodoxy heretofore utilized by Jewel as the first major apologist of England's Protestant national church as established by the Elizabethan Settlement: Scripture, the first four ecumenical councils, the writings of the church fathers, and custom of the primitive church. Together these criteria form a potent institutional canon which defined and affirmed orthodoxy while exposing and rejecting heresy. In this regard, Carleton makes trenchant use of each criterion to establish the orthodoxy of royal coercive jurisdiction in ecclesiastical affairs, and to confirm as heresy the papal prerogative of 'coactive' jurisdiction. In prosecuting his case by skillfully applying this doctrinal canon, Carleton distinguished Jurisdiction, Regall, Episcopall, Papall as probably one of the principal, if not the principal work defending royal supremacy in the Jacobean period, thereby refining application of the official canon for a new era faced by England's national church.

Upon reviewing the state of the question of royal ecclesiastical authority at the beginning of the treatise, Carleton proceeds to argue on the basis of Scripture, ancient philosophers and historians that cultic authority resided in kings as a consequence of natural law (Carleton 1610: 1-16). From there taking as his point of departure the arguments of Tudor apologists for royal supremacy, Carleton contends that magisterial ecclesiastical jurisdiction was divinely prescribed by the historical narratives of the Old Testament (Carleton 1610: 16-36; Gazal 2013). However, throughout the New Testament period this authority was somewhat inoperative since the Church was without a Christian magistrate. Nevertheless, the Church possessed disciplinary authority over its members in the form of excommunication, but it was void of the coercive element added to it by papal apologists as a measure to subordinate secular rulers to the will of the clergy (Carleton 1610: 37-59). Even within a Christian Roman Empire, Carleton observes, the Church's jurisdiction remained solely spiritual with a godly emperor exercising coercive power over it as acknowledged by the four ecumenical councils as the communal vehicles of patristic judgment.

Carleton interacts extensively with the contexts, procedures, and canons of these ancient councils in chapter 5 of the treatise. The central theme running through this chapter is that royal coercive ecclesiastical authority produced the councils that defined catholic consensus. 'There was no Councell held in Constantines time, whether or Orthodoxe or heretikes, but 
either by expresse commaundement, or license of the Emperour' (Carleton 1610: 62). Moreover, the emperor often utilized his 'coactive jurisdiction' to order re-examination of previous conciliar decisions. 'It was always held by all sober writers of the Church of Rome, as hereafter shall be further declared, that in the Church there is no power above the power of a Councell. And yet this authority of a Councell, so much and so worthily reverenced could not restraine Constantine, but he upon good and just causes brought the rash proceedings of some Councels to a new examination' (Carleton 1610: 61). Carleton states explicitly what previous apologists for royal supremacy like Jewel only implied: conciliar authority derives from royal ecclesiastical authority. Generally, the councils (especially the four ecumenical councils) performed two functions. First, they resolved theological disputes by defining doctrine, thereby providing the basis for orthodox, catholic unity. Secondly, the councils effected sundry disciplinary reforms for the church, an example of which is the First Nicene Council's formalization of public penance. Carleton construes both the doctrinal and disciplinary functions of the councils as having been essentially coercive which originated in the imperial or royal 'coactive' jurisdiction divinely invested in the emperor or the monarch. Thus, conciliar authority is delegated royal coercive ecclesiastical authority. For Carleton, the creation of councils by royal 'coactive jurisdiction' is one of the most conspicuous aspects of ancient church practice whose recovery is essential for the continuing reformation of Christendom, and the preservation of catholicity therein.

Carleton proceeds to substantiate his thesis by close examination of select ancient ecclesiastical historians, such as Rufinus of Aquileia and Theodoret. Appealing to Rufinus' Historia Ecclesia, Carleton contends that Constantine convoked Nicaea I at the request of Alexander, the Patriarch of Alexandria, to end the controversy provoked by the teaching of Arius, to show that ancient bishops willingly acknowledged the emperor's 'right and iurisdiction to call Councels' (Carleton 1610: 62). Moreover, Carleton interacts extensively with a dialogue between the Emperor Constans and Liberius, the bishop of Rome recorded by Theodoret in which the latter urges the former to call a council for the purpose of examining charges of heresy leveled against Athanasius so as to determine his guilt or innocence (Carleton 1610: 62). Undoubtedly with the intent to taunt Catholic opponents of James, Carleton is quick to point out that this bishop of Rome eventually acquiesced to pressure by Constans by helping to condemn Athanasius, and thus subscribe to Arianism (Carleton 1610: 62)—an episode confirmed by the Romanist historian Bartolomeo Platina (1421-1481) (Carleton 1610: 62). In elaborating on this dialogue, Carleton makes three observations. First, Liberius unambiguously confessed that 'Ecclesiastical iudgements are to be appointed and established by the Emperor' (Carleton 1610: 62). Since this 
judicatory authority originated in imperial ecclesiastical jurisdiction, the emperor then exercised it by convoking a council to deal with a theological matter. Secondly, 'the Emperor cannot make a man an hereticke, but this must be done by a Councell or iudgement Ecclesiasticall' (Carleton 1610: 62). Even though the emperor, from his rightful ecclesiastical authority, appointed councils for the purpose of determining orthodoxy, he, himself did not directly define doctrine and heresy, but rather acknowledged this duty as the function of bishops. Hence, the magisterial exercise of coercive ecclesiastical authority in this case extended only to the institution of the judicatory body through which the bishops could exert their 'authority' of Scriptural knowledge. Thirdly, as admitted by Liberius, he, and hence any bishop of Rome during this period, had no singular authority to judge other bishops (Carleton 1610: 63). The delegation of imperial coercive authority to the bishops via his calling of councils augmented their spiritual authority so as to enable them to enforce their judgment. This is because the bishops were now empowered to perform their function under imperial auspices. Carleton interprets this account by Theodoret as well as similar ones so as to argue that episcopal coercive power is not endemic to the episcopal office, but rather allocated by the imperial in whom it is divinely vested.

Carleton next directs his argument against the papal prerogative of calling general councils. In this regard, he engages at length chapter 12 of Robert Bellarmine's De Conciliis (Carleton 1610: 66-69), where he attempts to refute the Jesuit's contention that general councils can only be summoned with the pope's consent. Specifically, Bellarmine maintained that the convoking of general councils properly belonged to the Roman Pontiff. (Bellarmine 1605: 57). Moreover, in order for a synod to qualify as a general council, the pope must have appointed its meeting place, and ratify its judgments (Bellarmine 1605: 57). Any assembly that convenes apart from papal consent or commandment is not a council (concilium), but rather an unlawful committee (conciliabulum) (Bellarmine 1605: 57). Carleton responds with a sustained examination of the Council of Chalcedon (451).

Carleton commences his discussion with the observation that bishop Leo of Rome had no role in determining the location or the agenda of the council, but instead the emperors Valentinian and Marcian chose the city of Chalcedon as its meeting place and prescribed the agenda (Carleton 1610: 66). Significantly, Carleton notes that the emperors issued these instructions by way of a sacra, an official directive regulating public religious matters, the use of which they inherited from their pre-Christian imperial predecessors (Carleton 1610: 66-67; Gordon 1997: 127-132). Promulgation of the sacra by Christian emperors, according to Carleton, is the clearest indication of their lawful possession and exercise of ecclesiastical jurisdiction. For by their use of the sacra, the emperors "call councels, they punish offenders of the 
Clergy, they establish Ecclesiasticall Courts', showing that 'they are acknowledged the nourcing Fathers of Religion, the keepers and preservers of both Tables, and of the discipline of the Church' (Carleton 1610: 67). Imperial decree via the sacra was the most conspicuous exertion of 'coactive' ecclesiastical authority possessed by the Christian emperors. Hence, by their issuance of the sacrae, the emperors produced the councils.

Drawing from the Acts of the Council of Chalcedon, Carleton demonstrates Leo's unambiguous acknowledgement of imperial ecclesiastical authority to initiate general councils by 'decree' (sacra) (Carleton 1610: 67). Furthermore, Carleton (himself bishop of Llandaff) advances affirmation by the fifth-century bishop of Rome of the emperor's divinely ordained role directly under Christ, 'the true rule of godlinesse', 'the head of the Church', 'to correct ungodly things in the Church' (Carleton 1610: 67).

From Leo the Great's deferential correspondence with the emperor, Carleton deduces four characteristics of imperial ecclesiastical power recognized by the early church and confirmed by the Fathers. First, a general council is to be called 'only by the authority of the Emperor, imperiali decreto' (Carleton 1610: 67). Secondly, to the emperor has been divinely committed the custos disciplinae Ecclesiae, which, Carleton notes, encompassed specifically ecclesiastical affairs. As part of his historical analysis, Carleton points out that even though ecclesiastical authors of the period did not employ the phrase, 'ecclesiastical jurisdiction', they all, and in this case, Leo the Great, conceded the substance of what it later denoted as something rightfully possessed and exercised by the emperor 'as the preserver of the discipline Ecclesiasticall' (Carleton 1610: 67). Thirdly, the maintenance of the Church and its government 'for establishing the truth' belongs to the magisterial office as much as the power to wage war (Carleton 1610: 68). Finally, Christ, as the only 'head of the Church', delegates disciplinary authority over the Church to the prince (Carleton 1610: 68).

Carleton's thorough examination of the convening of the Council of Chalcedon, and trenchant analysis of Leo the Great's correspondence with the emperors who convoked it functioned as the pivotal patristic witness testifying to imperial power as the divinely appointed source of the ecclesiastical authority producing the councils as the definitive, judicatory and doctrinal bodies of the Church. The emperor, and hence, all Christian magistrates, possessing by divine appointment all ecclesiastical 'coactive authority' stand as one of the prime, if not the prime source of universal Christendom's catholic consensus.

\section{Conclusion}

Though combatting within different polemical contexts, John Jewel, Richard Hooker, and George Carleton defended the reformed Church of Eng- 
land established by the Elizabethan Settlement on the grounds of its fidelity to the ancient catholic Church as fundamentally defined by the first four general councils. These councils, which delineated the orthodoxy of the Church not only in terms of its doctrine, but also its governance. This is because they declared truth on behalf of the communal body of the Church as the congregatio fidelium. In Jewel's estimate, the Council of Trent negated its professed status as a general council because it contravened the first four general councils as expressions of the church's universal communal judgment.

In short, councils must encompass all sectors of the church in order for a genuine consensus regarding truth could be reached. Essential to this process was the biblical role of the godly prince in overseeing the process. Jewel disparaged the possibility of anymore true general councils since they have been supplanted by those dominated by the pope. However, councils as vehicles of consent could still take place because the ancient church provided the apparatus of national and regional synods. In highlighting national and regional synods, Jewel transferred to them the authority of general councils, effectively rendering them unnecessary.

About twenty-five years later Hooker parts with Jewel's pessimistic assessment of the continued utility of general councils by positing the restoration of this apostolic and ancient institution as a constructive means of establishing catholicity among different national churches, including Rome, on the basis of the common faith averred by the ecumenical creeds. Moreover, the first four general councils present an authoritative catholic consensus regarding penitential practice and the institution of episcopacy against which the Puritans stridently inveighed. Finally, during the reign of James VI/I amid the controversy surrounding the Oath of Allegiance, George Carleton sought to invalidate the pope's claim to 'coactive' jurisdiction which empowers him to depose a prince while excommunicating him/her.

To accomplish his purpose, Carleton located this 'coactive' jurisdiction in the divinely invested ecclesiastical authority of the prince. Throughout his examination of the first four general councils, Carleton argued that they derived directly from the emperors' 'coactive' jurisdiction which naturally stemmed from their ecclesiastical authority. Moreover, because these councils proceeded from imperial ecclesiastical authority, their enactments were subject to its approval.

Significantly, Carleton stressed the unqualified submission to this imperial ecclesiastical authority of convening general councils by the ancient bishops of Rome themselves. Because these councils that defined the Church's catholic consensus proceeded from imperial ecclesiastical authority, the Christian emperor himself by implication (and consequently Chris- 
tian monarchs) stood as the source of catholicity. Thus, for Carleton as well as Jewel, by ancient order royal assent begets catholic consent.

\section{References}

Bellarmine R (1605) De Controversiis Christianae Fidei, Adversus Huis Temporis Haereticos, Tomus Secundus. Ingolstadt: Adam Sartorii.

Bray G (1994) Documents of the English Reformation. Minneapolis, MN: Fortress Press.

Carleton G (1610) Jurisdiction Regall, Episcopall, Papall. London, UK: Printed by John Norton.

Gazal A (2013) Scripture and Royal Supremacy in Tudor England: The Use of Old Testament Historical Narrative. Lewiston, NY: Edwin Mellen Press.

Gordon R (1997) The Veil of Power. In Horsley R (ed) Paul and Empire Religion and Power in Roman Imperial Society. Harrisburg, PA: Trinity Press International.

Hooker R (1977a) The Laws of Ecclesiastical Polity. In Hill, WS and Edelen, G (eds) The Folger Library Edition of the Works of Richard Hooker, volume 1. Cambridge, MA: Belknap Press of Harvard University Press.

Hooker R (1977b) The Laws of Ecclesiastical Polity. In Hill, WS (ed) The Folger Library Edition of the Works of Richard Hooker, volume 2. Cambridge, MA: Belknap Press of Harvard University Press.

Hooker R (1981) The Laws of Ecclesiastical Polity. In Hill, WS (ed) The Folger Library Edition of the Works of Richard Hooker, volume 3. Cambridge, MA: Belknap Press of Harvard University Press.

Jewel J (2002) An Apology of the Church of England. New York, NY: Church Publishing.

Jones N (1982) Faith by Statute: Parliament and the Settlement of Religion, 1559. London, UK: Royal Historical Society. 